\title{
DDI POLEWALI MANDAR: ANTARA ADA DAN TIADA DDI Polewali Mandar: Between Being and 'f'fot
}

\section{Oleh: Muhammad Irfan Syuhudi*}

*Peneliti pada Balai Penelitian dan Pengembangan Agama Makassar Kantor: Jalan AP. Pettarani No. 72 Makassar Email: $\underline{\text { m_ippank/g)yahoo.com }}$

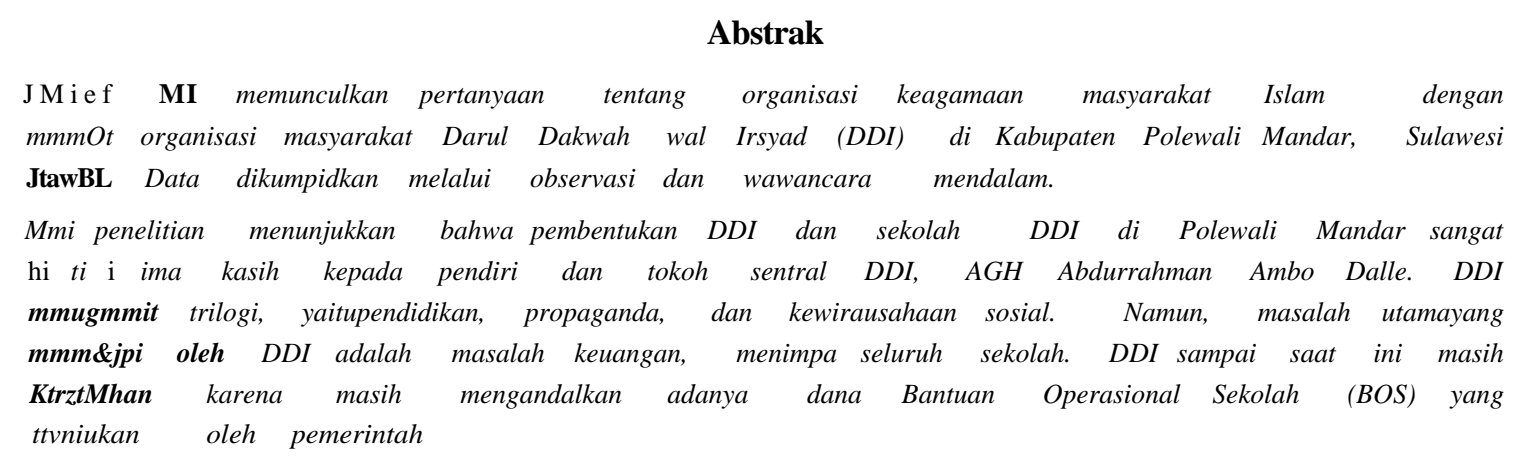

Kali kunci: organisasi masyarakat, DDI

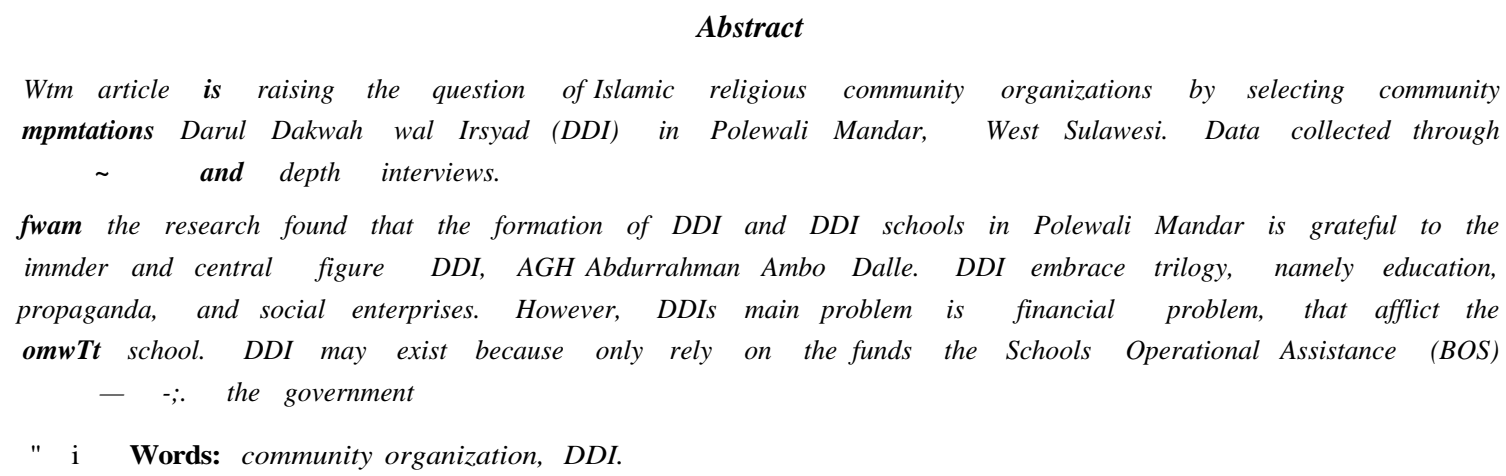

\section{HULL" AN}

edudukan organisasi kemasyarakatan dalam -.egara diatur dalam UU No. 8 Tahun 1985 Tentang Organisasi Kemasyarakatan. Pasal l.etentuan Umum) menyatakan, pengertian kemasyarakatan adalah organisasi yang xeh anggota masyarakat warganegara

- Indonesia secara sukarela atas dasar kegiatan, profesi, fungsi, agama. dan n terhadap Tuhan Yang Maha Esa, untuk -_n serta dalam pembangunan dalam rangka apai tujuan nasional dalam wadah Negara

$\mathrm{n}$ Republik Indonesia yang berdasarkan ila.

5-erdasarkan pada pengertian undang-undang di maka NU, Muhammadiyah, DDI, Al-Irsyad dan

i keagamaan lainnya dapat dimasukkan dalam pengertian sebagai organisasi kemasyarakatan yang bergerak di bidang keagamaan.

Pasal 5 dalam Bab III tentang Fungsi, Hak, dan Kewajiban menyatakan bahwa fungsi organisasi kemasyarakatan adalah:

a. wadah penyalur kegiatan sesuai kepentingan anggotanya;

b. wadah pembinaan dan pengembangan anggotanya dalam usaha mewujudkan tujuan organisasi:

c. wadah peran serta dalam usaha menyukseskan pembangunan nasional;

d. sarana penyalur aspirasi anggota, dan sebagai sarana komunikasi sosial timbal balik antar anggota dan/ atau antar organisasi kemasyarakatan, dan antara organisasi kemasyarakatan dengan organisasi kekuatan sosial politik, Badan Permusyawaratan/ Perwakilan Rakyat, dan Pemerintah. 
Berdasarkan konten pasal 5 di atas, ormas Islam memiliki fungsi dalam usaha menyukseskan pembangunan nasional khususnya di bidang agama. Dengan demikian, ormas Islam berfungsi untuk mendukung enam program keagamaan dalam rancangan (draft) RPJMN 2010-2014, poin pertama; meningkatkan kualitas pemahaman dan pengamalan agama masyarakat melalui upaya: a) peningkatan ketaatan beragama masyarakat agar terwujud dalam sikap dan perilaku sosial yang sejalan dengan nilai-nilai luhur yang terkandung di dalam ajaran agama; b). pengembangan wawasan keagamaan yang lapang dan toleran selaras dengan wawasan kebangsaan dan kebhinekaan; c) pengembangan pusat-pusat kajian keagamaan dan sumber belajar masyarakat; d) peningkatan ketersediaan dan pemanfaatan sumber-sumber informasi keagamaan dan perpustakaan rumah ibadah; e) pemanfaatan kemajuan yang dicapai dalam bidang TI dan komunikasi sebagai saranapembelajaran dan pengembangan nilainilai agama; dan f) peningkatan kesadaran dan penghargaan terhadap HAM dan kesetaraan gender di kalangan umat beragama.

Mengingat besarnya peran ormas Islam, draft RPJMN memberikan mandat kepada Kementerian Agama untuk melakukan peningkatan kualitas dan kapasitas lembaga sosial keagamaan² melalui, a) pengembangan sarana, prasarana, mutu manajemen, kualitas sumber daya pengelola lembaga sosial keagamaan, b) pemberian bantuan untuk penyelenggaraan berbagai kegiatan lembaga sosial keagamaan, dan penguatan program kelembagaan, c) peningkatan jaringan dan sistem informasi, d) peningkatan hubungan dan kerjasama antar lembaga sosial keagamaan dan dengan pemerintah sebagai mitra pembangunan, dan e) peningkatan pelayanan perpustakaan dan informasi keagamaan pada lembaga-lembaga sosial keagamaan.

Persoalannya, perhatian pemerintah terhadap eksistensi organisasi sejauh ini tidak terlalu besar. Di berbagai daerah, donasi dan bantuan pemerintah terhadap pemerintah hanya bersifat "reaktif'. Akibatnya, ormas Islam mengalami disfungsi. Banyak sekolahsekolah yang didirikan oleh ormas Islam yang akhirnya tidak dapat berkembang dengan baik karena kehabisan anggaran. Banyak kelompok pengajian yang akhirnya bubar dan tidak dapat melanjutkan programnya karena tidak ada yang serius menanganinya. Bahkan kecenderungan terakhir menunjukkan bahwa gerakan majelis taklim malah lebih banyak dilakukan oleh individu-individu atau lembaga masjid.^x"

Salah satu orrhas Islam yang menjadi fokus penelitian ini adalah Darul Dakwah wal Irsyad (DDI) di Polewali Mandar, Sulawesi Barat. Cikal bakal berdirinya DDI sungguh menarik. Mereka mempunyai trilogi gerakan, yakni pendidikan, dakwah, dan sosial. Lewat jalur pendidikan, DDI bertekad ingin mengentaskan atau mininal mengurangi buta aksara dan buta Al-Quran. Ini dibuktikan dengan pembangunan Madrasah Ibtidaiyah, Tsanawiyah, dan Aliyah. Bahkan, madrasah-madrasah DDI telah tersebar di beberapa daerah di Indonesia hingga ke luar negeri (Malaysia dan Brunei Darussalam). Selain itu, DDI juga getol menyiarkan Islam melalui jalur gerakan dakwahnya. Begitupula, DDI berusaha melebarkan sayap di bidang usaha sosial.

Berangkat pada latar belakang pemikiran di atas penelitian ini mengajukan pertanyaan penelitian sebagai berikut: Bagaimana eksistensi DDI dalam kehidupan sosial keagamaan masyarakat. Pertanyaan ini akan memberikan keleluasaan kepada peneliti untuk melihat sejauhmana keberadaan DDI turut mempengaruhi kehidupan sosial keagamaan masyarakat, terutama di Kabupaten Polewali Mandar, Sulawesi Barat.

Penelitian yang dilakukan pada 20.10 ini, merupakan penelitian kualitatif dengan analisis deskriptif. Pengumpulan data melalui observasi dan wawancara mendalam terhadap beberapa tokoh dan pengurus DDI di Polman, serta masyarakat yang berada di luar struktur ormas di lokasi penelitian.

Defenisi Operasional dan Ruang Lingkup Penelitian

a. DDI. DDI adalah singkatan dari Darul Dakwah Wal Irsyad. Lembaga ini didirikan padatahun 1947 di Soppeng oleh ulama Sulawesi Selatan. DDI yang menjadi sasaran penelitian adalah lembaga. madrasah, dan individu yang memiliki peran dalam kehidupan sosial masyarakat Polewali Mandar.

b. Kehidupan Keagamaan. Yang dimaksud kehidupan keagamaan dalam konteks penelitian ini adalah keseluruhan bangunan keberagamaan

RPJMN ini masih bersifat draft dan belum disahkan secara resmi sebagai bagian dari grand desain pemerintah. Lihat lebih jauh dalam sambutan Prof. Dr. H.M. Atho Mudzhar. 2009. Pengembangan Jaringan Riset dalam Rangka Penguatan Peran Agama dalam Pembangunan Nasional. Jakartal: Badan Litbang dan Diklat Departemen Agama RI

Lihat draft RPJMN poin keenam. 
individu maupun masyarakat mulai dari akidah, peribadatan, moralitas, hingga relasi sosial antar dan intra umat beragama.

c. Pendidikan Keagamaan. Berdasarkan pada PP No. 55 Tahun 2007 tentang pendidikan agama dan keagamaan Bab III pasal 9, penelitian in memahami pendidikan keagamaan sebagai keseluruhan model penyelenggaran baik melalui pendidikan formal seperti sekolah Islam, pesantren, dan madrasah maupun pendidikan non formal (atau dalam istilah PP tersebut dengan pendidikan keagamaan) seperti majelis taklim, pengajian keagamaan dan kelompok diskusi keagamaan.

4. Masyarakat. Penelitian ini memahami masyarakat sebagai sekelompok penganut agama Islam yang berada dalam wilayah kabupaten Polewali Mandar, baik perkotaan maupun pedesaan.

\section{"mjauan Pustaka}

\section{vadi Ormas Islam Indonesia}

Islamic studies telah menjadi agenda kajian -iidemik yang populer sejak lama. Snouck --rgrounje dikenal sebagai salah satu intelektual ang getol mempelajari Islam untuk kepentingan ».:>,onial Belanda. ${ }^{4}$ Pascakolonial, penelitian tentang $\sim^{\wedge} \mathrm{s}>$ arakat Islam yang paling berpengaruh adalah - tian Clifford Geertz yang memetakan Islam Nategori abangan dan santri, tradisionalis dan TMOernis. NU direpsentasikan sebagai kelompok --.a (abangan dan tradisional), dan Muham- diyah dalam kategori kedua (modernis). ${ }^{5}$ Meski

- -:".gan banyak sarjana Islam yang melakukan

- :erhadap kajian Geertz, tetapi kategorisasi

- dan santri, tradisional dan modern masih

-B p digunakan.
Penelitian tentang ormas Islam di lingkungan Badan Litbang dan Diklat Departemen Agama pun telah banyak dilakukan. Seperti penelitian tentang "Respon Pemerintah, Ormas, Masyarakat terhadap Aliran Keagamaan di Indonesia. ${ }^{6}$ Penelitian ini memosisikan ormas sebagai bagian dari kelompok dominan yang memandang kelompok aliran sebagai sesuatu yang berjarak. Oleh karena itu, kelompok jamaah tabligh, LDII, Ahmadiyah dipahami sebagai aliran keagamaan bukan organisasi keagamaan.

Penelitian dengan pendekatan serupa pernah dilakukan oleh tim peneliti Balai Litbang Agama Makassar tahun 2007.' Kedua penelitian ini tidak secara fokus meneliti tentang organisasi keagamaan dalam konteks kelembagaan, tetapi representasi ormas melalui tokoh-tokohnya sebagai subyek yang memberi penilaian kepada aliran-aliran yang dianggap berbeda dengan mainstream masyarakat Islam.

\section{Ormas Islam sebagai CSO (Civil Society Organi- zation)}

Menurut Dawam Rahardjo, konsep civil society sangat identik dengan cita-cita Islam membangun ummah, suatu tatanan masyarakat yang merdeka dan berkarakter sesuai dengan moralitas agama. Dawam melihat keterkaitan erat antara agama dan kebangkitan civil society. Di Polandia misalnya peranan Katolik tidak bisa diabaikan dalam kebangkitan masyarakat sipil. Sulit untuk menyatakan kesadaran kelas menjadi penggerak perubahan karena di negara itu tidak dikenal kelas kapitalis, karena itu pendorong perubahan berasal dari agama. ${ }^{8}$

Suatu kenyataan sejarah dalam masyarakat Indonesia pasca-kolonial, bahwa keberadaan ormas keagamaan seperti NU, Muhammadiyah, Persis,

PP No 55 tahun 2007 tentang pendidikan agama dan keagamaan mendefenisikan; 1) pendidikan agama sebagai pendidikan yang - :--ar, pengetahuan dan membentuk sikap, kepribadian, dan keterampilan peserta didik dalam mengamalkan ajarannya, yang dilaksanakan "x£-<urangnya melalui mata pelajaran/kuliah pada semua jalur, jenjang, dan jenis pendidikan; 2) pendidikan keagamaan sebagai pendidikan e-persiapkan peserta didik untuk dapat menjalankan peranan yang menuntut penguasaan pengetahuan tentang ajaran agama dan atau ic ahli ilmu agama dan mengamalkan ajaran agamanya (lihat PP. No. 55 tahun 2007 tentang Pendidikan Agama dan Pendidikan arr-un Bab 1 pasal 1).

stian Snouck Hurgronje 1991. Nasihat-Nasihat C Snouck Hurgrounje Kepada Pemerintah Hindia Belanda (Terj.Sukarsi). Jakarta: riifford Geertz. 1964. The Religion of Java. London: The Free Press of Glencoe.

"in jauh Haidlor Ali Ahmad (ed). 2007. Respon Pemerintah. Ormas. Masyarakat terhadap Aliran Keagamaan. Jakarta: Badan Litbang $\sim 1 v$. Puslitbang Kehidupan Keagamaan Jakarta.

Ibd Kadir Ahmad (ed). 2007. Varian Keagamaan Islam. Makassar: Balai Penelitian dan Pengembangan Agama. fcwam Rahardjo. 1996. "Agama dan Masyarakat Madam' dalam Seri Dialog Kebudayaan I. Jakarta:LSAF-Kompas-Paramadina). 
DDI dan sebagainya menjadi lokus sosial yang sangat berpengaruh pada perjalanan bangsa. Pergulatan politik tanah air dan perubahan orientasi politik sangat ditentukan oleh tokoh-tokoh yang berasal dari ormas ini.'

Relasi ormas Islam dan politik pun sangat fluktuatif. Kadang-kadang mengambil posisi vis a vis dengan negara (terutama pada zaman orde baru), tetapi juga kadang-kadang integral dengan situasi politik nasional(eramultipartai 1955-1972 dan 1999-sekarang dengan munculnya PKB, PAN sebagai wujud lain dari NU dan Muhammadiyah).

\section{Temuan dan Pembahasan}

\section{Setting Sosial Keagamaan Masyarakat Polman}

Kabupaten Polman masuk dalam wilayah tentorial Provinsi Sulbar. Selain Polman, empat kabupaten lain yang berada dalam wilayah provinsi termuda di Indonesia ini adalah Majene, Mamasa, Mamuju, dan Mamuju Utara. Polman dihuni oleh etnis Mandar yang merupakan suku asli, seperti halnya kabupaten lain di wilayah ini.

Kendati dihuni berbagai etnis seperti Makassar, Bugis, Jawa, dan lain-lain sebagai pendatang dan kemudian memilih menetap, namun penduduk di Polman mayoritas beretnis Mandar, yaitu sekitar 68 persen. Sedangkan kabupaten terbesar yang beretnis Mandar di Sulbar adalah Majene (96 persen). Di Mamuju, etnis Mandar sebesar 30 persen, Bugis 15 persen, dan sisanya Jawa, Toraja, Makassar, dan lain-lain. Di Mamuju Utara, penduduk beretnis Mandar hanya selisih sedikit dengan Bugis, yang berjumlah lebih banyak. Etnis Jawa, Toraja, dan Makassar, juga banyak terdapat di kabupaten ini. Sedangkan di Mamasa, didominasi 85 persen Toraja. ${ }^{10}$

Mayoritas penduduk di Polman beragama Islam, yaitu 371.272, termasuk pendatang seperti Bugis, Makassar, dan transmigran Jawa. Jumlahnya terpaut cukup jauh dengan penduduk beragama Kristen, yang mencapai 4.261 jiwa. Selengkapnya lihattabel berikut:
Tabel 1.

Jumlah Penduduk Menurut Agama di Kabupaten Polman

\begin{tabular}{|c|l|c|}
\hline No & \multicolumn{1}{|c|}{ Agama } & Jumlah Pemeluk \\
\hline 1 & Islam & 371.272 jiwa \\
\hline 2 & Kristen & 4.261 jiwa \\
\hline 3 & Katolik & 2.147 jiwa \\
\hline 4 & Budha & 127 jiwa \\
\hline 5 & Hindu & 207 jiwa. \\
\hline \multicolumn{2}{|c|}{ Jumlah } & 378.015 jiwa \\
\hline
\end{tabular}

Sumber: Kantor Kemenag Kab. Polman 2008.

Tabel di atas menunjukkan, perkembangan Islam di Polman cukup baik dan pesat. Secara historis kultural, ini juga tidak terlepas dari peran Kerajaan Balanipa (nama kerajaan ini diabadikan menjadi salah satu kecamatan di Polman), yang menjadikan Islam sebagai agama resmi kerajaan. Maradia atau raja Balanipa pertama yang menganut agama Islam adalah Mara'dia Balanipa keempat, yaitu Daetta Tommuane atau Kanna I Pattang pada abad XVI.

Kerajaan Balanipa merupakan salah satu dari 14 kerajaan di Tanah Mandar dan termasuk ke dalam tujuh kerajaan yang terletak di Muara Sungai (Pitu Ba'bana Binanga). Sedangkan tujuh kerajaan lainnya berada di Hulu Sungai (Pitu Ulunna Salu). Menurut Darmawan Mas'ud (ke-14 kerajaan ini masing-masing menjalankan pemerintahan secara otonomi. Mereka akhirnya bersatu dan kemudian membentuk federasi dengan tujuan untuk melawan penjajah."

Soal siapa yang pertama kali menyiarkan Islam di Kerajaan Balanipa dan beberapa sumber menyebut nama Abdurrahim Kamaluddin. Katanya, kedatangan Abdurrahim ke daerah ini berawal ketika perahunya berlabuh di pantai Tammangalle (ada juga menyebut di Tinambung dan berlabuh di Pelabuhan Para). Namun. berbeda dengan beberapa daerah lain, yang ketika Islam masuk terlebih dahulu menaklukkan daerah bersangkutan. maka Islam masuk dan berkembang di Tanah Mandar tidak melalui kekerasan atau perang. Islam masuk melalui cara damai atau proses dialog intelektual. ${ }^{12}$

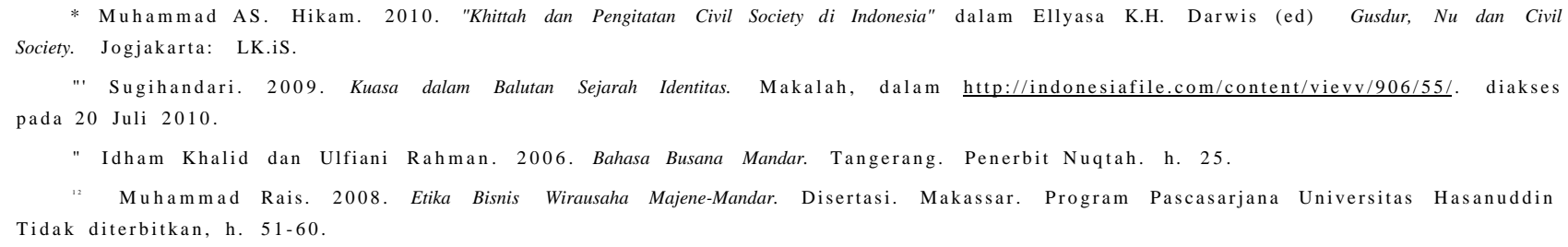


Perkenalan dan penyebaran Islam pertama kali -2.3. dilakukan dengan metode sufistik. Tampaknya, - ira seperti ini lebih mudah diterima oleh masyarakat ang saat itu menganut kepercayaan animisme dan : namisme. Metode ini dianggap cukup toleran karena - •enerima kearifan-kearifan lokal yang kerapkali <iijiimpai dalam kehidupan keagamaan, sehingga :ii daya tarik bagi masyarakat setempat.

Di Sulbar, ada semacam pembagian kategori politis idap beberapa kabupaten.Misalnya, Polman dikenal : igai sentra industri, Majene kota pendidikan, dan

u kota birokrasi atau pemerintahan sekaligus

- ta provinsi. Mesk'i begitu, Polman sebenarnya juga ng kota pendidikan berbasis Islam. Setidaknya, :ierah ini banyak berdiri beberapa sekolah serta " iga pendidikan mulai taman kanak-kanak hingga --sitas. Untukperguruantinggi, terdapatUniversi-

5; ari'ah Mandar (Unasman) dan Sekolah Tinggi 1 a m a Islam DDI.

Menurut mantan Rektor Unasman, KH Sybli addin, mahasiswanya pada 2010 ini berjumlah

'. 0 orang. Mereka itu bukan saja berasal dari ", atau Sulbar, melainkan juga dari luar seperti nsi Sulawesi Selatan, Sulawesi Tenggara, esi Tengah, dan Kalimantan. Kampusnya ir di beberapa tempat di Sulbar. Sementara STAI

- C L jumlah mahasiswanya mencapai ribuan orang. ] uga ada yang berasal dari luar Sulbar. Bahkan,

- meningkatkan kualitas kampus serta sumber

- manusia, Ketua STAI DDI, Anwar Sewang,

.- . mukakan, pihakiiya bekerja sama dengan Uni-

tas Islam Negeri (UIN) Makassar tengah mnijajaki program pascasarjana strata tiga (doktor).

3 erbeda dengan perguruan tinggi, madrasah DDI - gkat Ibtidaiyah (SD), Tsanawiyah (SMP), dan ah1 SMA), berjumlah lebih banyak. Madrasah ini ang dikelola pihak yayasan (berstatus swasta) -" - u g a di bawah naungan pemerintah (berstatus -cirri). Menariknya, jumlah madrasah DDI me-

- - Kan madrasah negeri yang dikelola pemerintah.

. - _.. iumlahnyaterpaut cukup jauh. Jelasnya lihat rerikut.

\section{label 2. Jumlah Madrasah Negeri/Swasta} di Kabupaten Polman

\begin{tabular}{c|c|c|c|c|c|}
\hline \multicolumn{2}{|c|}{ Ibtidaiyyah } & \multicolumn{2}{c|}{ Madrasah } & Tsanawiyah & \multicolumn{2}{c|}{ Madrasah } & Aliyah \\
\hline & $\begin{array}{c}\text { Swasta } \\
62\end{array}$ & $\begin{array}{c}\text { Negeri } \\
2\end{array}$ & $\begin{array}{c}\text { Swasta } \\
27\end{array}$ & $\begin{array}{c}\text { Negeri } \\
2\end{array}$ & $\begin{array}{c}\text { Swasta } \\
8\end{array}$ \\
\hline 65 & \multicolumn{2}{|c|}{29} & \multicolumn{2}{|c|}{10} \\
\hline
\end{tabular}

Data Emis Kementerian Agama Kab. Polman 2010
Mendominasinya madrasah yang dikelola pihak swasta, seperti diperlihatkan pada tabel di atas, menunjukkan bahwa masalah pendidikan sebenarnya bukan hanya tanggung jawab utama pemerintah. Dalam hal ini, pihak swasta pun merasa ikut bertanggung jawab untuk mencerdaskan bangsa. Sebagai bukti keseriusan pihak swasta memberantas kebodohan, jnadrasah-madrasah ini telah ada sekitar tahun 1940^an dengan nama Madrasah Arabiyah Islamiyah (MAI). Dinamakan demikian karena pada umumnya niadrasah tersebut adalah sekolah berbasis Islam dan dikelola oleh ulama-ulama lokal. Nanti setelah pertemuan ulama se Sulsel digelar di Watang Soppeng pada 1947 , barulah MAI di Polman berubah nama menjadi madrasah DDI.

\section{Perkembangan Organisasi Keagamaan di Polman}

Sejauh ini, perkembangan ormas Islam di Sulbar, khususnya di Polman, sudah berjalan bagus. Ormas Islam yang mula-mula masuk dan secara kelembagaan terbentuk adalah NU dan Muhammadiyah. Kemudian, setelah itu diikuti ormas-ormas Islam lain, termasuk DDI. Khusus ormas DDI, tidak ada data yang pasti kapan mulai masuk di daerah ini karena pengurusnya tidak menyimpan data resmi terkait hal tersebut. Beberapa informan hanya memperkirakan pada 1960an, ditandai dengan terbentuknya kepengurusan periode pertama pada 1962 .

Namun, dibandingkan organisasinya, madrasah DDI sebenarnya lebih duluan ada. Madrasah DDI berdiri pada 1948 dengan nama Madrasah Ibtidaiyah Mapilli di Jalan Majene 1, Polman. Hanya saja, pada saat itu madrasah ini belum berafiliasi ke DDI dan masih bernama Madrasah Arabiyah Islamiyah (MAI). Nanti setelah resmi bergabung ke DDI, barulah namanya diganti menjadi madrasah ibtidaiyah. Sementara, Madrasah Tsanawiyah yang pertama dibangun pada 1967, yaitu MTs DDI Polewali di Jalan Kemakmuran No 191, Polman.

Selain DDI, ormas Islam lain yang ada di Polman adalah Majelis Ulama Indonesia (MUI), Majelis Dakwah Islamiyah (MDI), Dewan Masjid Indonesia (DMI), dan lain-lain. Organisasi kemahasiswaan Islam pun tak ingin ketinggalan. Maka, dibentuklah Pergerakan Mahasiswa Muslim Indonesia (PMII) dan Himpunan Mahasiswa Islam (HMI). Setelah kran demokrasi terbuka yang ditandai dengan bergulirnya reformasi (1998), ormas Islam yang berdiri di Polman cuma AL-Wasliyah (WAS). Hingga 2010, kelembagaan 
Islam/ormas Islam yang tercatat di Kantor Kementerian Agama Polman sebanyak32. Lebih lengkapnya, lihat tabel berikut ini.

Tabel 3.

\section{Lembaga Keagamaan/Ormas Islam di Kabupaten Polman}

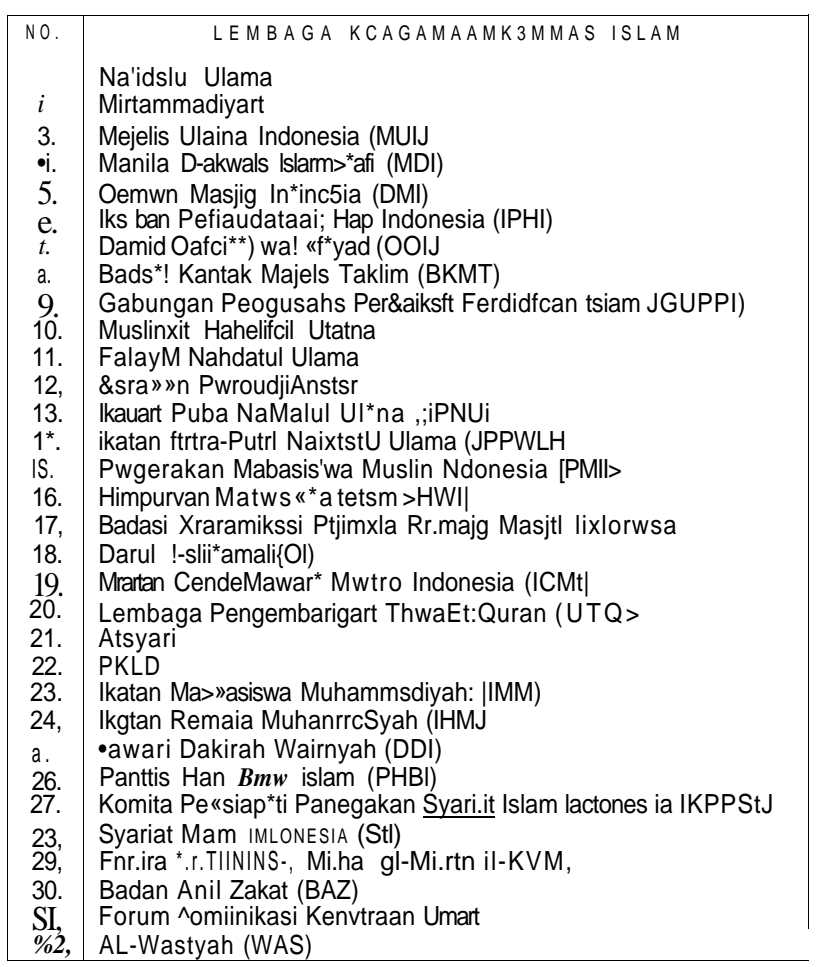

Data: Kementerian Agama Kabupaten Polman 2010.

Perkembangan kelembagaan/ormas Islam di Sulbar, khususnya lagi di Polman, seperti ditunjukkan • pada tabel di atas, secara kuantitas boleh dikata tergolong pesat. Boleh jadi, "kesuksesan" tersebut lantaran Sulbar pada waktu itu belum menjadi provinsi karena masih berada di dalam wilayah teritorial Sulsel. Praktis, ormas-ormas Islam di Sulbar yang tadinya hanya sebagai cabang atau ranting dari ormas Islam di Sulsel, kemudian berubah menjadi pimpinan wilayah. Sebagai ibukota provinsi, Sulbar baru berumur enam tahun sejak resmi memisahkan diri dari Sulsel pada 2006. Dari 33 provinsi di Indonesia, Sulbar termasuk provinsi termuda.

Sebagai mayoritas berpenduduk Islam, lembaga dan ormas itu difungsikan oleh masyarakat sebagai sarana untuk memecahkan persoalan sosial keagamaan yangterjadi di daerahnya. Bagi sebagian besar masyarakat awam, mereka yang duduk di dalam kelembagaan dan ormas Islam itu dianggap sebagai sekumpulan orang-orang cerdas lantaran berasal dari kalangan intelektual muslim. Apalagi, setiap kali menangani persoalan sosial keagamaan, ormas Islam tersebut acapkali mendapat bantuan atau bekerja sama dengan pemerintah setempat sebagai "penguasa".

\section{Mengingat Kembali Sejarah Ormas DDI di Polman}

Cukup sulit menyebutkan tanggal dan bulan berapa ormas DDI terbentuk di Polman. Data yang didapat hanya memperkirakan tahun berdirinya saja, yaitu sekitar 1960-an. Mereka mengacu kepada terbentuknya kepengurusan pertama pada 1962. Periode pertama (1962-1971) adalah H Rasyid Sulaeman dan H Rahman Ali, yang masing-masing menjabat ketua dan sekretaris. Pada periode kedua (1971-1976) dan ketiga (1976-1981) dipegang H Rahim Ali (ketua) dan H Anwar Madising (sekretaris). Selanjutnya, periode keempat dijabat Shadiq Najamuddin dan H Anwar Madising.

Para pengurus DDI di atas sangat berperan besar terhadap lahirnya DDI di Polman. Sebagai murid langsungnya Ambo Dalle, mereka merasa berkewajiban mengembangkan dan menerapkan ilmuyang didapatkan dari sang guru di kampung halamannya. Maka, untuk memperkuat keberadaannya, mereka pun sepakat membentuk DDI di Polman dengan memilih H Rasyid Sulaeman sebagai ketua. Dengan membentuk organisasi, posisi mereka tentunya bisa lebih kuat ketimbang harus bergerak sendiri-sendiri. Setelah membentuk ormas, langkah berikutnya adalah membangun madrasah. Maka, berdirilah Madrasasah Tsanawiyah DDI Polewali pada 1967. Madrasah pertama ini terletak di Jalan Kemakmuran.

Soal sulitnya melacak sejarah DDI di Polman. diakui pula Abdul Haris Nawawi, pengurus teras DDI di Polman. Haris, yangjuga Kepala Sekolah MTs DDI Polewali, mengakui tidak ada pengurus yang menyimpan arsip penting itu.

Memang, madrasah DDI pertama di Polman adalah Madrasah Ibtidaiyah di Mapilli. Madrasah ini sudah berdiri sejak 1947. Namun, seperti disebutkan sebelumnya, sekolah ini awalnya sekolah Arab yang bernama Madrasah Arabiyah Islamiyah (MAI). Perubahan nama MAI menjadi madrasah DDI terjadi setelah pertemuan penting para ulama se-Sulsel di Watang Soppeng pada 1947. Pertemuan ini juga dihadiri Andregurutta (AG) H Abdurrahman Ambo Dalle, tokoh utama sekaligus pendiri DDI. Boleh dikata, pertemuan ini merupakan embrio dari berdirinya madrasah-madrasah DDI di Tanah Mandar. 
Atenjamurnya" madrasah-madrasah DDI di : man juga berkatjasa beberapa alumninya. Setelah rerguru di Ambo Dalle, para alumni itu kemudian "c-rarik mendirikan madrasah di daerahnya masing"ising. Tak lupa, para alumni juga menyertakan nama I DI di belakang nama madrasahnya setelah terlebih rulu meminta restu kepada Ambo Dalle. Ambo Dalle cak keberatan orang-orang menggunakan nama DDI. Vlalah, ia sendiri ikut menyarankan agar sekolah$-\mathrm{c}^{\wedge}$ olah Islam melekatkan nama DDI.

\section{Terjadi Dua Faksi: DDI MK dan DDI AD}

Pada 1960-an, diduga telah terjadi proses Kris- si di pelosok-pelosok pedesaan di Tanah Mandar, asuk di Polman. Sasarannya adalah mereka yang [•scara ekonomi miskin dan hidup jauh dari keramaian.

- melawan upaya Kristenisasi itu, pemerintah toerah di bawah naungan Departemen Agama $\wedge$.<arang Kementerian Agama) melakukan per-

- ".in dengan menyebarkan guru agama, beberapa

- - :aranya orang-orang DDI, ke daerah-daerah yang -.an sasaran Kristenisasi. Warga yang sempat -at dan pindah ke agama Kristen akibat bantuan ?mi, kembali diislamkan lagi oleh guru-guru a. Pada masa ini, departemen agama juga banyak imsrekrut alumni DDI yang sebelumnya hanya guru di sekolah-sekolah swasta atau guru mengaji

- idi pegawai negeri sipil.

- elah Ambo Dalle meninggal pada 29 November terjadi pergolakan di internal ormas DDI. Selama $\sim$ nbo Dalle dianggap sebagai tokoh utama DDI dan - erekat antar sesama warga DDI. Perkataan dan

-..n\ a menjadi rujukan dalam mengelola organisasi :engurus besar hingga paling bawah. Sampai-

" . . Ambo Dalle tak bisa dipisahkan dari DDI; DDI Ambo Dalle dan Ambo Dalle adalah DDI.

- nlah, semua pengelola madrasah dan pengurus

JDL mulai pengurus besar hingga tingkat bawah ..kan murid-murid Ambo Dalle. ${ }^{13}$

varena Ambo Dalle sebagai figur utama sudah ada (meninggal), maka puncaknya, kubu DDI ilami disintegrasi. Perpecahan ini terjadi setelah lar ke-19 di Makassar pada 26 September A DDI yang telah banyak melahirkan ulama, menjadi dua faksi, yakni DDI lama, yang siasikan dengan nama pemimpinnya, yaitu Abdul : Kabry (DDI MK) serta DDI baru yang dibentuk oleh M Faried Wadjedy dan kawan-kawan, yang kemudian dikenal dengan DDI Ambo Dalle (DDI AD). Perpecahan ini diikuti pula oleh cabang-cabang yang tersebar di daerah-daerah/Untuk wilayah Polman, DDI lama atau DDI MK diketuai Anwar Sewang. Sedangkan DDI AD dipimpin KH Sybli Sahabuddin, yang pelantikannya dilaksanakan pada Juli 2010 di Kampus Unasman, Polman. Pelantikan Sybli, yangjuga anggota DPD utusan Sulbar, dihadiri Gubernur Sulbar, Anwar Adnan Saleh.

\section{Eksistensi Ormas DDI di Polman}

\section{Sebagai Lembaga Pendidikan}

DDI sejak dulu dikenal dengan sistem lembaga pendidikan formalnya yang berbentuk madrasah dan pesantren. Bahkan, eksistensi tersebut hingga kini tetap dipertahankan sebagai bentuk dari identitas diri. Penguatan pada sektor lembaga pendidikan itu didasarkan kepada salah satu trilogi DDI yang memang serius memberantas kebodohan melalui kegiatan pendidikan. Seperti disebutkan sebelumnya, madrasah DDI telah ada di Polman sejak tahun 1948. Awalnya bernama Madrasah Arabiyah Islamiyah (MAI), yang kemudian berganti nama menjadi Madrasah Ibtidaiyah di daerah Mapilli.

Sejak saat itulah, madrasah binaan DDI tampak "menjamur". Apalagi, DDI tidak pernah melarang orang-orang yang ingin mendirikan sekolah atau mengganti nama sekolahnya dengan mengatasnamakan DDI. Meski banyak yang menggunakan nama DDI, pengelolaan madrasahnya tidak dilakukan oleh DDI sebagai suatu lembaga organisasi. Di sinilah ironisnya. Sebagai lembaga pendidikan, DDI itu merupakan aset nasional karena tidak hanya terdapat di Sulsel dan Sulbar, melainkan juga telah melebarkan sayap sampai ke Kalimantan, Papua, hingga ke mancanegara (Malaysia dan Brunei Darussalam).

Basman Said mengatakan, pihak DDI tidak pernah melarang orang-orang yang ingin mendirikan madrasah dan memakai nama DDI, meskipun mereka itu bukan pengurus atau anggota DDI. Justru, pendiri DDI, Ambo Dalle, yang menganjurkan agar madrasah melekatkan nama DDI di belakang nama sekolah mereka.

Jadi, madrasah DDI dibangun bukan melalui proses yang matang atau lewat desain organisasi. Pembangunan madrasah pada saat itu lebih disebabkan 
oleh ketertarikan personal saja kepada DDI. Dalam hal ini, ketokohan Ambo Dalle sebagai ulama besar yang dikagumi dan disegani di Sulsel, dan bahkan Indonesia, menjadi daya tarik tersendiri untuk merintis sebuah usaha bisnis (madrasah). Apalagi tidak ada persyaratan khusus bagi yang ingin menggunakan nama DDI. Alhasil, pada 1960-an hingga 1980-an, madrasah-madrasah yang mencantumkan nama DDI mulai bermunculan, mulai tingkat Ibtidaiyah (SD), Tsanawiyah (SMP), dan Aliyah (SMA). Salah satu tujuan memberikan label DDI di madrasahnya adalah untuk memikat siswa baru.

Di antara madrasah tersebut, jumlah Madrasah Ibtidaiyah ternyata yang paling banyak, yaitu berjumlah 47 madarsah, disusul Tsanawiyah dan Aliyah masingmasing 7 dan 2. Lebih jelasnya lihat tabel berikut:

Tabel 4. Madrasah Ibtidaiyah DDI di Polman

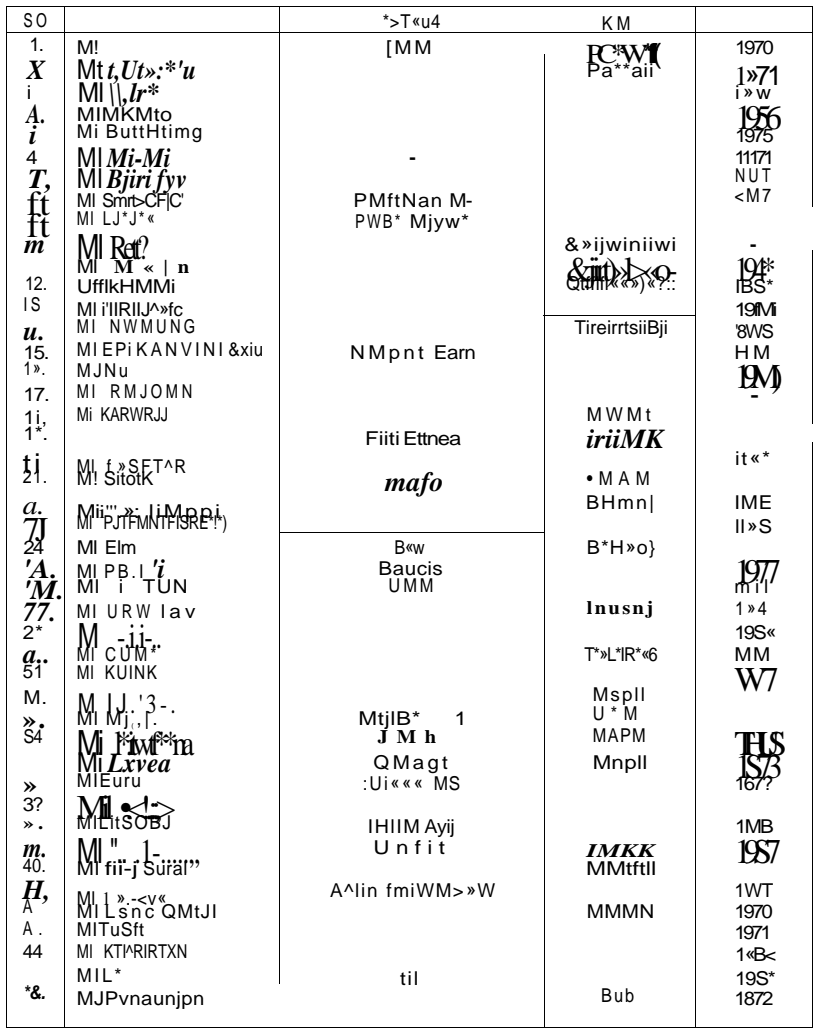

Sumber: Data Emis Kementerian Agama Kabupaten Polman 2010

Tabel 5. Madrasah Tsanawiyah DDI di Polman

\begin{tabular}{|c|c|c|c|c|}
\hline & & $3 s s s$ & & $\mathrm{nmfl}$ \\
\hline J". & 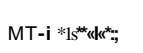 & KMinnmiiin K 191 & PIMMB & $\begin{array}{l}19 * ? \\
972\end{array}$ \\
\hline 4. & 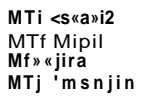 & $M z \& m \$ k i 1$ EARN ${ }^{*}$ & $\begin{array}{l}\text { itapH } \\
\left(\mathrm{Ml}^{*}\right.\end{array}$ & $\begin{array}{l}19515 \\
\text { IMN }\end{array}$ \\
\hline
\end{tabular}

Sumber: Data Emis Kementerian Agama Kabupaten Polman 2010
Tabel 6. Madrasah Aliyah DDI di Polman

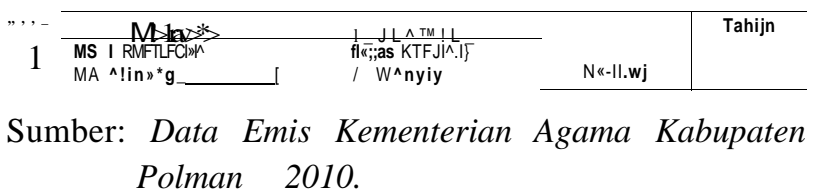

Kurikulum yang diajarkan pada madrasah DDI di Polman, yakni penggabungan antara kurikulum dari Kementerian Agama dan Pendidikan Nasional. Mata pelajaran agama untuk tingkat Tsanawiyah dan Aliyah, antara lain, bahasaArab, aqidah akhlak, fiqih, dan sejarah Islam. Sementara kurikulum pelajaran umum sama seperti sekolah-sekolah umum lainnya.

Mengacu pada tiga tabel di atas, tak bisa dipungkiri kalau madrasah DDI mulai tingkatan MI, MTs, dan MA, cukup berkibar di Tanah Mandar, termasuk di Polman. Bahkan, terdapat beberapa madrasah di kabupaten. Di Polman, misalnya, terdapat enam MI. Begitupula di Kabupaten Binuang, yang memiliki 12 MI. Sedangkan MTs dan MA, ada beberapa kabupaten yang membangun madrasah DDI, meski jumlahnya tidak sebanyak MI.

\section{Dulu Kebanjiran Murid, Kini Andalkan BOS}

Masa-masa kejayaan madrasah DDI terlihat pada 1980-an dan 1990-an. Ketika itu, para orang tua lebih memilih menyekolahkan anak-anaknya di madrasah DDI ketimbang sekolah-sekolah negeri atau swasta lainnya. Para orang tua tertarik karena bangga melihat alumni madrasah ini cenderung mempunyai wawasan pengetahuan agama Islam yang mendalam. Mereka yang pernah mengenyam pendidikan di madrasah DDI, beberapa di antaranyajugaterjun menjadi guru agama pada madrasah-madrasah dan sekolah-sekolah serta menjadi ustadz.

Jumlah madrasah DDI yang ada di Polman tidak ditunjang oleh kelengkapan sarana. Boleh dikatakan, madrasah DDI pada umumnya minim fasilitas. Hal seperti inilah yang kerapkali dikeluhkan oleh para pengurus madrasah. Tak heran, bangunan sekolah madrasah DDI boleh digolongkan model bangunan tua yang terlihat kurang perawatan. Cat temboknya tampak mulai pudar dan terkelupas. Atapnya yang terbuat dari seng banyak pula kelihatan berkarat. Demikian pula peralatan lain, seperti bangku, meja, dan papan tulis. Alhasil, madrasah DDI pun perlahanlahan kalah bersaing dengan sekolah-sekolah umum berstatus negeri yang kebanyakan mempunyai fasilitas lebih lengkap. 
iran nama DDI jika merujuk pada .mlah madrasah yang dimiliki (seperti pada 5. dan 6), ternyata tidak berimbas kepada -caal. Buktinya, sampai saat ini seluruh madrasah geluhkan kekurangan dana. Beruntung, berbaik hati mengeluarkan kebijakan $\wedge \cdot a c(B O S)$

engucurkan dana Bantuan Operasional

\section{DDI sebagai Ormas Islam: Antara Ada dan Tnda}

." - $r$ ormas Islam, peran DDI belum dirasakan u oleh masyarakat Islam secara keseluruhan. reran DDI sama seperti ormas Islam lain, >ebatas menangani isu-isu yang kebetulan : am kehidupan masyarakat. Nyaris tidak ada - -i" matang dalam mengatasi isu tersebut. $m a$ lerlihat serba instan dan berlaku hanya pada •ya fenomena yang dianggap meresahkan.

s aja, ini berbeda ketika DDI melaksanakan bidang pendidikan (sesuai isi dari salah - $n \backslash$ a: pendidikan, dakwah, dan usaha sosial). imbaga pendidikan, DDI adalah ujung a rjendidikan karena bertekad memberantas

- Dalam hal ini, DDI merasaperlu dan wajib ^•ggungjawab membantu pemerintah mencer$\mathrm{km}$ kehidupan bangsa. Bentuk keseriusan DDI -":= gan banyaknya jumlah madrasah (MI, MTs,

Ji Polman, seperti disebutkan pada bagian Btamya.

-rti disebutkan di atas, DDI memang cukup $f$ Biembaca isu-isu kontemporer serta menang-abila ada aliran/ajaran keagamaan yang - - . > esatkan. Dua kasus yang dianggap besar

aitu munculnya ajaran yang menyimpang I islam mainstrem (salat bersiul dan Pomalea), en pa waktu lalu. Hanya, dalam mengatasi isu-isu -amaan tersebut, DDI tidak pernah bergerak irnan alias selalu mengajak dan melibatkan lerntah dan ormas Islam lain. Apalagi, kerja sama

gan pemerintah dan ormas-ormas memang -alan baik. Dalam menyelesaikan persoalan- an keagamaan tersebut, DDI, pemerintah, serta 1 Islam lain lebih memilih menyelesaikan secara aasif seperti melakukan pembinaan ketimbang LA a anarkis, seperti yang biasa dilakukan ormas I Pembela Islam (FPI).

g disayangkan, sebagai sebuah lembaga si, DDI di Polman tidak memiliki sekretariat. al. salah satu persyaratan elementer dari sebuah organisasi adalah memiliki sekretariat. Ini juga yang menyulitkan peneliti ketika pertama kali akan menelusuri jejak sejarah masuknya DDI di Polman. Karena tidak memiliki sekretariat, peneliti akhirnya mendatangi pengurus secara person. Selain itu, ormas ini juga tidak menyimpan arsip kesejarahan. Misalnya, peristiwa-peristiwa yang dianggap penting atau fenomenal seputar perjalanan DDI dari masa ke masa. Sebagai organisasi lokal yang namanya me-nasional dan berumur puluhan tahun, DDI seharusnya memiliki sarana dan fasilitas tersebut di tingkat wilayah, daerah, maupun tingkat cabang (khususnya di Polman). Kalau pun misalnya ada dokumentasi foto-foto kegiatan ormas yang bisa ditunjukkan, itu sifatnya hanya koleksi pengurus untuk kenang-kenangan pribadi.

Di samping itu, cukup sulit membedakan antara orang DDI dan NU secara personal. Faktanya, orang DDI adalah kebanyakan orang NUjuga. Soal adanya identitas ganda itu (DDI dan NU), dibenarkan oleh Abdul Haris Nawawi. Menurutnya, DDI dan NU itu ibarat bersaudara karena kebanyakan pengurus DDI terdiri atas orang-orang NU. Abdul Haris sendiri adalah orang NU dan menjabat pengurus teras di DDI Polewali. Hanya saja, tidak semua orang DDI itu adalah guru karena ada juga yang bekerja di pemerintahan (pegawai negeri sipil), perusahaan swasta, dan dan wiraswasta.

Yang jadi masalah, ketika menangani persoalan sosial keagamaan, maka masyarakat awam tentu akan kesulitan membedakan siapa ormas penggerak di belakangnya; apakah DDI ataukah NU? Padahal, ini penting untuk tetap menjaga eksistensi dan apresiasi DDI terhadap masyarakat sekitarnya.

\section{Trilogi DDI: Pendidikan, Dakwah, dan Usaha Sosial}

Sejak awal berdirinya, DDI konsisten dengan konsep trilogi yang dibangunnya yaitu bergerak di bidang pendidikan, dakwah, dan usaha sosial. Namun, dari ketiga konsepsi yang dilahirkan oleh para pendirinya ini, hanya pendidikan dan dakwah yang boleh dikata bersentuhan langsung dengan masyarakat banyak. Sedangkan di bidang usaha sosial, sasarannya lebih mengarah untuk menghidupi ormas DDI.

\section{a. Bidang Pendidikan}

Siapa pun pasti sepakat, perjuangan DDI di bidang pendidikan agama Islam sangatlah besar. Berdirinya beberapa madrasah dan pesantren di Tanah Manda, termasuk di Polman, mulai tingkat MI, MTs, dan MA, 
menjadi salah satu bukti konkritnya. Bukan itu saja. Hasil dari didikan madrasah ini banyak pula melahirkan para ulama dan tokoh-tokoh agama.

Selain madrasah, ormas DDI juga membina beberapa Majelis Taklim dan panti asuhan. Khusus Majelis taklim, beberapa pengurus DDI menjadi pembina dan pendiri.

\section{b. Bidang Dakwah}

Memang, tidak salah kalau orang-orang beranggapan DDI itu "gudangnya" para dai. Sejak didirikan oada 1947, salah satu orientasi DDI adalah menciptakan kader-kader yang memiliki wawasan luas keagamaan. Sebagai bukti, orang-orang DDI pada umumnya bisa berceramah atau terjun menjadi dai. Bahkan, kalau pemerintah setempat menggelar kegiatan yang berkaitan dengan keagamaan dan membutuhkan siraman rohani, maka yang dipanggil adalah orang-orang DDI.

\section{c. Bidang Usaha Sosial}

Berbeda dengan bidang pendidikan dan dakwah, yang boleh dikata tergolong sukses lantaran mempunyai madrasah serta melahirkan dai-dai. Maka, untuk bidang sosial, DDI seolah tidak mampu berbuat apa-apa. Selama ini, usaha sosial DDI hanya bertumpu pada koperasi yang dijalankan di madrasah-madrasah. Sejatinya, usaha sosial ini dipadukan juga dengan kegiatan ekonomi yang bertujuan untuk menghidupkan organisasi lewat uang kas. Sayang, segala upaya yang dilakukan pengurus lewat usaha sosial ekonomi guna menghasilkan uang untuk menghidupi organisasi, ternyata belum berhasil.

Usaha sosial ekonomi yang sempat dilakukan, antara lain, menetapkan pembayaran iuran reguler yang dibebankan kepada setiap pengurus. Tentunya, dari pemungutan iuran ini diharapkan dapat membantu berjalannya roda organisasi.

Kepengurusan DDI mulai tingkat wilayah hingga ranting pun tidak bisa berharap banyak mendapat suntikan dana dari pimpinan pusat. Apalagi, pimpinan di pusat pun memiliki persoalan sama, yakni tidak punya dana. Dengan tidak adanya bantuan dana tersebut, praktis ormas DDI dituntut mampu berpikir kreatif agar program kerjanya bisa berjalan sebagaimana mestinya.

\section{Peran Yang (Mulai) Bergeser?}

Peran DDI sebagai ormas Islam selama beberapa puluh tahun belakangan telah mengalami pergeseran. Bila dibandingkan tahun 1950an-1980an, DDI sekarang telah mengalami penurunan yang sangat signifikan. Madrasah-madrasah yang dikelola oleh DDI (atau yang berlabel DDI) saat ini dalam kondisi yang sangat memprihatinkan. Secara fisik, sebagian besar telah mengalami kerusakan dan tidak pernah direnovasi. Apalagi madrasah DDI yang berada di pedesaan, kondisinya lebih memprihatinkan.

Di luar itu, animo masyarakat untuk menyekolahkan anaknya di madrasah DDI tidak lagi terlalu tinggi. Selain karena fasilitas di DDI tidak terlalu baik. juga karena status madrasah DDI sebagai sekolah swasta. ${ }^{14}$ Saat ini, ada beberapa madrasah DDI yang hanya mengandalkan dana BOS (Bantuan Operasional Sekolah) sebagai andalan untuk bertahan hidup. Dana ini digunakan untuk menggaji guru dan melakukan aktivitas pembelajaran sebagaimana mestinya. Ini karena organisasi tidak memiliki sistem fund rising yang dapat menghidupi sekolah mereka secara mandiri. Program sosial ekonomi yang menjadi salah satu dari agenda DDI tidak berjalan dengan baik. Situasi ini cukup mengkhawatirkan bagi pengurus madrasah DDI.

Di luar konteks madrasah, DDI sebagai organisasi juga tidak dapat dikatakan baik. DDI tidak dikelola sebagaimana layaknya organisasi. Memang ada struktur yang jelas, tetapi mekanisme pengambilan keputusan tidak berjalan dengan baik. Biasanya hanya berlangsung berdasarkan inisiasif dari ketua, tidak berangkat dari mekanisme keorganisasian yang disusun secara sistematis. Ini menunjukkan karakter DDI lebih berorientasi paguyuban ketimbang organisasi modern.

Satu-satunya peran yang masih bisa diharapkan dari DDI adalah peran para dai yang bekerja secara individual dan beredar di hampir semua struktur sosial masyarakat dan para guru yang berada di madrasah. Meski mereka kadang-kadang tidak bergerak dalam "instruksi" organisasi, tetapi kehadiran mereka sangat penting dalam memelihara pemahaman keagamaan yang mayoritas dipahami oleh masyarakat Islam Mandar di Kabupaten Polewali Mandar.

Ada asumsi yang berkembang di masyarakat, sekolah swasta dianggap lebih rendah mutu-nya dibandingkan dengan sekolah negeri. Ini sebetulnya terkait dengan bantuan pemerintah yang lebih banyak ke sekolah negeri. Beberapa tahun belakangan, memang ada kebijakan kementrian agama Polman yang ingin me-negeri-kan beberapa madrasah DDI, namun ini ditolak oleh pengurus DDI, karena proses pe-negeri-an hanya akan menghilangkan sejarah DDI itu sendiri. 


\section{PENUTUP}

\section{Mmpulan}

Ormas Islam DDI di Tanah Mandar, khususnya di *;bupaten Polman, mulai terbentuk sekitar 1960-an. $\mathrm{i}$ itandai dengan terbentuknya kepengurusan periode :<e-Mma pada 1962. Setelah itu, lima tahun kemudian, "irulah madrasah DDI pertama didirikan di Polman,

: MTs Polewali di Jl Kemakmuran Nomor 191, yang : "ingun pada 1967. Namun, jauh sebelumnya, yaitu :.iia 1948, madrasah DDI sebenarnya telah ada dan remama Madrasah Ibtidaiyah di Mappili. Hanya saja, - lirasah ini awalnya merupakan Madrasah Arabiyah amiyah (MAI) yang kemudian berafiliasi menjadi madrasah DDI.

Terbentuknya ormas DDI dan madrasah DDI : Polman tak lepas dari jasa pendiri sekaligus tokoh

i. AGH Abdurrahman Ambo Dalle. Pada saat ito. beberapa putra Mandar berguru langsung ke -iangkoso, yang menjadi pusat organisasi DDI. >erulang dari menimba ilmu itulah, putra Mandar ini kemudian membentuk ormas DDI serta ;-dirikan madrasah dengan tetap melekatkan

:as DDI di belakang nama madrasahnya. Bukti

M kuatnya pengaruh DDI adalah dengan tentyaknya madrasah di Polman, yaitu Madrasah

- iaiyah berjumlah 47 buah, MTs (7), dan MI (2). kondisi madrasah DDI sekarang ini cukup r-iprihatinkan. Karena tidak punya anggaran, ridrasah hanya berharap bantuan dari pemerintah

ik mengucurkan dana Bantuan Operasional a (BOS).

Eksistensi ormas DDI juga dikategorikan 5 di Polman. Setidaknya, ormas ini proaktif -.nasi setiap kali ada isu-isu keagamaan porer yang masuk ke daerah ini. Seperti, 'alnya, ketika Sumardi membawa ajaran yang yimpang dari Islam mainstrem (salat sambil ml) dan kasus Pomalea, yang terjadi beberapa ixtu lalu.

Namun, problem utama yang dihadapi DDI adalah ah finansial, yang menimpa seluruh madrasahnya. na persoalan tidak punya dana inilah, sehingga Msah DDI dapat terus eksis lantaran hanya gandalkan dana Bantuan Operasional Sekolah S i yang diberikan pemerintah. Bukan hanya itu. nisasinya pun kesulitan dana sehingga tidak punya tariat. Keaktifan ormas ini dalam urusan sosial

laan lebih ditunjukkan oleh pengurusnya secara idu. bukan lembaga.

\section{Rekomendasi}

1. Pemerintah Daerah setempat dengan memberi perhatian lebih terhadap madrasah DDI, khususnya dalam soal pembangun infrastruktur.

2. Secara internal, DDI perlu melakukan re-visi dan re-inventing posisi mereka di tengah masyarakat Mandar yang telah mengalami perubahan sosial politik.

\section{Ucapan Terima Kasih}

Penelitian ini dibiayai oleh anggaran DIPA Balai Litbang Agama Makassar pada 2010. Karena itu, saya berterima kasih kepada Balai Litbang Agama Makassar yang mengikutkan saya pada penelitian ini, serta Saprillah (peneliti Balai Litbang Agama Makassar), yang merupakan rekan tim dalam penelitian ini. Saya juga berterima kasih kepada jajaran redaksi Jurnal Al-Qalam yang bersedia memuat tulisan ini. Tak lupa pula saya mengucapkan terima kasih kepada informan, antara lain, Abdul Haris Nawawi, Basman Said, dan Kahar Masbi, yang selalu meluangkan waktunya kepada kami.

\section{DAFTARPUSTAKA}

Ahmad, Abd._ Kadir (ed). 2007. Varian Keagamaan Islam. Makassar: Balai Penelitian dan Pengembangan Agama.

Ahmad, Haidlor Ali (ed). 2007. Respon Pemerintah, Ormas, Masyarakat terhadap Aliran Keagamaan. Jakarta: Badan Litbang dan Diklat Puslitbang Kehidupan Keagamaan Jakarta.

Bodi, Muh. Idham Khalid dan Ulfiani Rahman. 2006. Bahasa Busana Mandar. Jakarta: Penerbit Nuqtah.

Geertz, Clifford. 1964. The Religion of Java. London: The Free Press of Glencoe.

Hikam, Muhammad AS. 2010. "Khittah dan Penguatan Civil Society di Indonesia" dalam Ellyasa KH. Darwis (ed) Gusdur, $\mathrm{Nu}$ dan Civil Society. Jogjakarta: LKiS

Hurgronje. Cristian Snouck. 1991. Nasihat-Nasihat C Snouck Hurgrounje Kepada Pemerintah Hindia Belanda (Terj.Sukarsi). Jakarta: INIS.

Rahardjo, M. Dawam. 1996. "Agama dan Masyarakat Madam" dalam Seri Dialog Kebudayaan I. Jakarta:LSAF-KompasParamadina).

Rais, Muhammad. 2008. EtikaBisnis Wirausaha Majene-Mandar Makassar, Disertasi. Program Pascasarjana Universitas Hasanuddin. Tidak diterbitkan.

Sugihandari. 2009. "Kuasa dalam Balutan Sejarah Identitas". Makalah, dalam http://indonesiafile.com/content/view/906/ 55/. diakses pada 20 Juli 2010. 